INTERNATIONAL HIGHER EDUCATION Number 74 Winter 2014

Pages 14-15

\title{
Europe's 25 Years of Internationalization: The EAIE in a Changing World
}

HANS DE WIT and FIONA HUNTER

Hans de Wit is director of the Centre for Higher Education Internationalisation at the Università Cattolica Sacro Cuore in Milan, Italy, and professor of Internationalisation of Higher Education at the Amsterdam University of Applied Sciences, the Netherlands. He is a founding member and past president of the European Association for International Education. E-mail: j.w.m.de.wit@hva.nl. Fiona Hunter is a consultant on higher education and research associate at the Center for Higher Education Internationalisation. She is also a past president of the European Association for International Education. Email: fionajanehunter@gmail.com.

With the flagship program of the European Union (ERASMUS) created in 1987 and the European Association for International Education (EAIE) founded in 1989 in Amsterdam, Europe met numerous changes. Promoting student mobility was considered a part of foreign policy. Historical ties with former colonies, political and economic policies, and traditional mobility of the elites (both from former colonies to Europe and from Europe to Northern America) dominated the international education scene. Trade in education, cross-border delivery, and branch campuses were present in the 1980s but marginal to higher education 
discourse and policies. There were no international rankings of universities. Bologna was only a city and Italy's oldest university. Cooperation prevailed with commercialization, and competition concerned obscure Anglo-Saxon phenomena that would never reach the continent.

Earlier, institutional and national policies were absent, as well as any European policy for internationalization; but, 25 years later the European Commission has just published its first comprehensive internationalization strategy: European Higher Education in the World. Also, EAIE has celebrated its 25th, and the largest ever, conference in Istanbul with 4,800 participants from all over the world.

\section{The EAIE: Needs and Changing Realities}

The EAIE responded to current needs and changing realities in European higher education: in the early years, the Erasmus Programme and then other European Commission initiatives for education, research, and development cooperation both within and beyond Europe; the inclusion of education in the 1992 Maastricht Treaty; and the ensuing increased attention by national governments and higher education institutions to internationalize.

Although the main focus had been mobility, the EAIE had always considered the issue of the other 90 percent of nonmobile students and in 1999 launched the "Internationalisation at Home" movement. It has increasingly considered a central element of internationalization strategies, today one of the key pillars of the new internationalization strategy of the European Commission, and together with mobility and partnerships. 
The EAIE grew from a start-up to the reality of a living, and working association in a period in which the pace of Europe's political and economic integration and its higher education sector accelerated amid much excitement, innovation, cooperation, and expansion. Both the EAIE and European Commission policies were driven by a powerful vision and strong ideals of a united Europe, of equal access to higher education, and of international education as a core activity in the curriculum, not only for personal development but as the way to build a better world. They were years of optimism and faith in the European future, and it was against this backdrop that the Bologna Declaration was signed in 1999.

\section{EURopeAn Higher EdUCATION FOR OTHER Regions}

The Bologna process was conceived and developed well because of the extremely positive experience and influence of cooperation under Erasmus, hailed as one of the most ever successful European initiatives. Initially, the principal focus was on the internal dimension of putting the European House for the purpose of greater commonality in degree structures, credit systems, and quality assurance; but it quickly acquired an external dimension. The emerging European Higher Education Area not only created an external identity for European higher education institutions, but it also generated a strong interest for the new instruments and models in other world regions, even though they may not always have been fully implemented across Europe.

In the same period, the European Union extended its membership from 15 to 27 countries and the euro was introduced as a single currency. However, the 
sense of integration and related economic and political security of a single European space soon came under threat, first by the tragic attack on the Twin Towers in New York on September 11, 2001, then the rejection of the European Constitution by Dutch and French voters in 2005, and more recently the global and European economic problems, triggered by the 2008 world financial crisis.

At the same time, European Higher Education was facing the powerful pressures of globalization and the emergence of the knowledge economy, shifts in economic balances and demographics, and an accelerating information technology revolution. The 2000 Lisbon Strategy of the European Council strived, perhaps over-ambitiously, to make the European Union the most competitive and dynamic knowledge-based economy in the world. Global rankings began to impact as universities thought about themselves and based on how their role was perceived by society and industry at large, requiring them to change at an unprecedented pace.

\section{The EMerging Business of Higher Education}

The EAIE conference grew rapidly because new international education professions were emerging in what was now increasingly being termed the "business of higher education." On the contrary, it became Europe's key competitive advantage. Strategic partnerships, joint programs, double degrees, and other collaborative projects featured high on the conference program. As the EAIE conference goes from strength to strength, Europe is experiencing greater uncertainty in the grips of a global economic crisis. The European dream, which so greatly influenced the creation of the EAIE 25 years ago, is being seriously 
challenged. The creation of European citizenship, a key objective in European programs, seems to be slipping away.

In higher education, new providers emerge challenging traditional university models. The rapid rise of private higher education, both nonprofit and for-profit, has become a global phenomenon capturing 30 percent of the student population. New forms of higher education appear, with massive open online courses being hailed as the new game changer.

\section{NEW Opportunities}

Universities are expected to become key players in the global knowledge economy, and internationalization is identified as a key response to globalization. This has radically altered the understanding of internationalization in universities, as it shifts from being a marginal to mainstream activity, no longer located exclusively in the international offices, but an integral part of university strategy.

This requires significant rethinking, and each university must interpret internationalization in the specific context of its own mission. The increased focus on intercultural, international, and global competences and learning outcomes of graduates and staff, the link between internationalization, employability, and citizenship require new approaches and strategies and new methods for outcomes and impact. Is internationalization still all "motherhood and apple pie"? Or will the so-called darker sides of internationalization generate tensions that will detract from the reasons that make international education 
beneficial? Will we see more or less "Europe" in the next decade? Also, how will this affect its relations with other world regions?

Inevitably, more change lies ahead as fundamental questions are asked about the roles and responsibilities of higher education and, consequently, of the purpose and scope of internationalization. The new European Commission policy and the continuing strength of EAIE as a knowledge hub in European and international higher education will provide a new platform for those questions to be asked, and hopefully answered, in the next 25 years.

This is a shortened and updated version of the first chapter by the authors in the book Possible Futures, The next 25 years of the Internationalisation of Higher Education, published by the EAIE on the occasion of its 25th anniversary, 2013/2014 (www.eaie.org). 